\title{
ENVIRONMENTAL VARIATION IN SEED AND SEEDLING CHARACTERISTICS OF PINUS ROXBURGHII SARG. FROM UTTARAKHAND, INDIA
}

\author{
S.K. GHILDIYAL - C.M. SHARMA* - S. GAIROLA \\ Department of Botany, HNB Garhwal University, Post Box 51, Srinagar Garhwal-246 174 \\ Uttarakhand, India \\ *Corresponding author \\ e-mail:sharmacmin@gmail.com, skghildiyal@gmail.com,sumeetgairola@hotmail.com
}

(Received $29^{\text {th }}$ August 2007 ; accepted $6^{\text {th }}$ July 2009)

\begin{abstract}
The present study was undertaken to assess the environmental variation in seed characters and to explore the efficacy of hydrogen peroxide treatment on the germination and seedling traits of sixteen provenances of Pinus roxburghii from Uttarakhand Himalaya. Provenances, which had higher values for seed parameters showed better germination. Soaking the seeds for 24 hours in a solution of $\mathrm{H} 2 \mathrm{O} 2(1 \%$ $\mathrm{v} / \mathrm{v}$ ) had a significant effect on the rate of germination and average germination percentage. About $88.5 \%$ of mean average germination was revealed by the seeds that were treated with $\mathrm{H} 2 \mathrm{O} 2$ as compared to the untreated (control) seeds (77.4\%). Simultaneously, $\mathrm{H} 2 \mathrm{O} 2$ treatment also caused an appreciable decrease, in shortening of germination period by 10 days. Results have shown that the soaking of chir-pine seeds in $\mathrm{H} 2 \mathrm{O} 2(1 \% \mathrm{v} / \mathrm{v})$ for 24 hours is highly beneficial and therefore for large scale germination, treatment of $\mathrm{H} 2 \mathrm{O} 2$ should be preferred. The germination percentage of seeds was found to be positively correlated with altitude and negatively correlated with rainfall.
\end{abstract}

Keywords: Garhwal Himalaya, Provenance, Altitude, Hydrogen per oxide treatment, Seedling height.

\section{Introduction}

The natural regeneration of different plant species through seeds depends upon the production and germination capacity of the seeds and the successful establishment of the seedlings. Seeds from healthy, well formed trees provide greater assurance that the resulting stock will have good form, survival and resistance against stress conditions. A tree species may extend over the large geographical area and can grow in wide range of environments with varying climate and topography. It usually has local populations adapted to the different environment at conditions, known as provenances. After knowing the range of adaptation of a species its populations may become more important in forest restoration, as global warming and other environmental changes disrupt natural forests (Ledig \& Kitzmiller, 1992). In provenance trials, provenances from varying climatic conditions are compared to asses the seed quality. As an early step towards improvement of tree species, provenance trials provide prerequisite knowledge of both genetic and environmental variations, which allow direct genetic comparisons among seed sources growing in multiple "common gardens" and are ideally suited to quantify impacts of changing climate on wood production (Kitzmiller, 2005).

Pinus roxburghii Sargent, commonly known as 'Chir pine' is the most important pine among the six indigenous pine species of India, which is much valued for its timber and oleoresin. It occurs in the monsoon belt of the outer Himalaya, from North eastern part of Pakistan to Arunachal Pradesh in India at elevations varying from 450 to $2300 \mathrm{~m}$ asl. It is found distributed over a long strip of about $3,200 \mathrm{~km}$ between latitudes $26^{\circ} \mathrm{N}$ to $36^{\circ} \mathrm{N}$ and longitudes $71^{\circ} \mathrm{E}$ to $93^{\circ} \mathrm{E}$. The species is economically very important 
and is used for variety of purposes viz., timber for house construction, fuel wood extraction, charcoal formation, growing trees stems for resin tapping, needles for fuel briquetting, cattle bedding and manufacturing organic manure, etc.

Work on seed testing of various provenances of Pinus roxburghii from Uttarakhad and Himachal Himalaya has been done by Sharma et al. (Sharma et al., 2001), Ghildiyal et al. (2007), and Ghildiyal and Sharma (2005, 2007), whereas, Isoenzyme analysis on different provenances of Chir pine from the Indian subcontinent has been done by Hussain (1995) from Pakistan, and by Sharma (1999) and Sharma (2007) from India. The germination capacity of seeds is strongly influenced by abiotic factors such as temperature, water stress and, in certain cases, light, which often show a significant influence on germination (Knipe, 1973; Rao \& Singh, 1985). Several growth hormones and chemicals like $\mathrm{H}_{2} \mathrm{O}_{2}$ have been found to enhance the rate of seed germination in may species viz., in spruce (Chandra \& Chauhan, 1976), Northofagus obliqua and $N$. procera (Shafiq, 1980), Pinus wallichiana (Thapliyal et al., 1985), V, Pinus roxburghii (Ghildiyal, 2003) etc, through which losses in seed germination could be minimised (Quarberg \& Jahns, 2000). In this study we have tried to assess the variation in seed characters and an effort was made to explore the efficacy of hydrogen peroxide treatment on the germination and seedling characters of 16 provenances of Pinus roxburghii collected from Garhwal Himalaya.

\section{Materials and methods}

The study was conducted on the seed and seedling characteristics of 16 provenances of Pinus roxburghii collected from different geographic locations, which were distributed in 4 districts i.e., Pauri, Chamoli, Rudraprayag and Tehri of Uttarakhand state in India (latitude $29^{\circ} 26^{\prime}$ to $31^{\circ} 28^{\prime} \mathrm{N}$ and longitude $77^{\circ} 49^{\prime}$ to $80^{\circ} 06^{\prime} \mathrm{E}$ ). The majority of rain fall $(1000 \mathrm{~mm}$ to $1800 \mathrm{~mm})$ in these regions occur during monsoon period i.e., from June to September, and are represented by sub-tropical to temperate climates. The detailed geographical and meteorological attributes of various provenances are given in Table 1. \& Fig.1.

Table 1. Geographical and meteorological descriptions of different provenances of Pinus roxburghii.

\begin{tabular}{|c|c|c|c|c|c|c|c|}
\hline \multirow[t]{2}{*}{ Provenance } & \multirow[t]{2}{*}{ District } & \multirow{2}{*}{ Latitude (N) } & \multirow{2}{*}{ Longitude (E) } & \multirow{2}{*}{$\begin{array}{l}\text { Altitude } \\
\text { (m) }\end{array}$} & \multicolumn{2}{|c|}{ Temperature } & \multirow{2}{*}{$\begin{array}{l}\text { Mean annual } \\
\text { rainfall }(\mathrm{mm})\end{array}$} \\
\hline & & & & & Min. & Max. & \\
\hline Ashtavakra & Pauri & $30^{\circ} 13^{\prime}$ & $78^{\circ} 48^{\prime}$ & 960 & 5.76 & 37.70 & 705.00 \\
\hline Agustmuni & Rudraprayag & $30^{\circ} 23^{\prime}$ & $79^{0} 02^{\prime}$ & 875 & 4.31 & 36.59 & 833.00 \\
\hline Badiyargarh & Tehri & $30^{\circ} 17^{\prime}$ & $78^{0} 50^{\prime}$ & 1080 & 7.50 & 36.30 & 930.00 \\
\hline Ghansali & Tehri & $30^{\circ} 27^{\prime}$ & $78^{\circ} 39^{\prime}$ & 890 & 5.00 & 34.60 & 1230.00 \\
\hline Godnar & Chamoli & $30^{\circ} 30^{\prime}$ & $79^{\circ} 16^{\prime}$ & 1680 & 1.30 & 24.00 & 1890.00 \\
\hline Jaiharikhal & Pauri & $29^{\circ} 47^{\prime}$ & $78^{\circ} 32^{\prime}$ & 960 & 7.54 & 37.00 & 1150.00 \\
\hline Jasholi & Rudraprayag & $30^{\circ} 16^{\prime}$ & $79^{\circ} 04^{\prime}$ & 1520 & 1.60 & 34.10 & 1025.00 \\
\hline Kalimath & Chamoli & $30^{\circ} 34^{\prime}$ & $79^{\circ} 05^{\prime}$ & 1540 & 1.60 & 26.10 & 1257.50 \\
\hline Lansdowne & Pauri & $29^{\circ} 50^{\prime}$ & $78^{\circ} 41^{\prime}$ & 1703 & -0.90 & 25.80 & 1260.00 \\
\hline Mayali & Tehri & $30^{\circ} 23^{\prime}$ & $78^{\circ} 47^{\prime}$ & 1400 & 2.60 & 25.10 & 1030.00 \\
\hline Pabo & Pauri & $30^{\circ} 15^{\prime}$ & $79^{\circ} 01^{\prime}$ & 1640 & 1.8 & 32.4 & 875.00 \\
\hline Pauri & Pauri & $30^{\circ} 09^{\prime}$ & $78^{\circ} 48^{\prime}$ & 1660 & -0.48 & 26.30 & 1792.00 \\
\hline Pokhal & Tehri & $30^{\circ} 25^{\prime}$ & $78^{\circ} 59^{\prime}$ & 820 & 5.70 & 37.63 & 800.00 \\
\hline Tangni & Chamoli & $30^{\circ} 29^{\prime}$ & $79^{\circ} 28^{\prime}$ & 1480 & 4.20 & 25.50 & 990.00 \\
\hline Thalisain & Pauri & $30^{\circ} 02^{\prime}$ & $79^{\circ} 03^{\prime}$ & 1640 & 1.9 & 31.00 & 1025.00 \\
\hline Vana & Chamoli & $30^{\circ} 38^{\prime}$ & $79^{\circ} 05$ & 1610 & 1.30 & 24.00 & 1660.00 \\
\hline
\end{tabular}




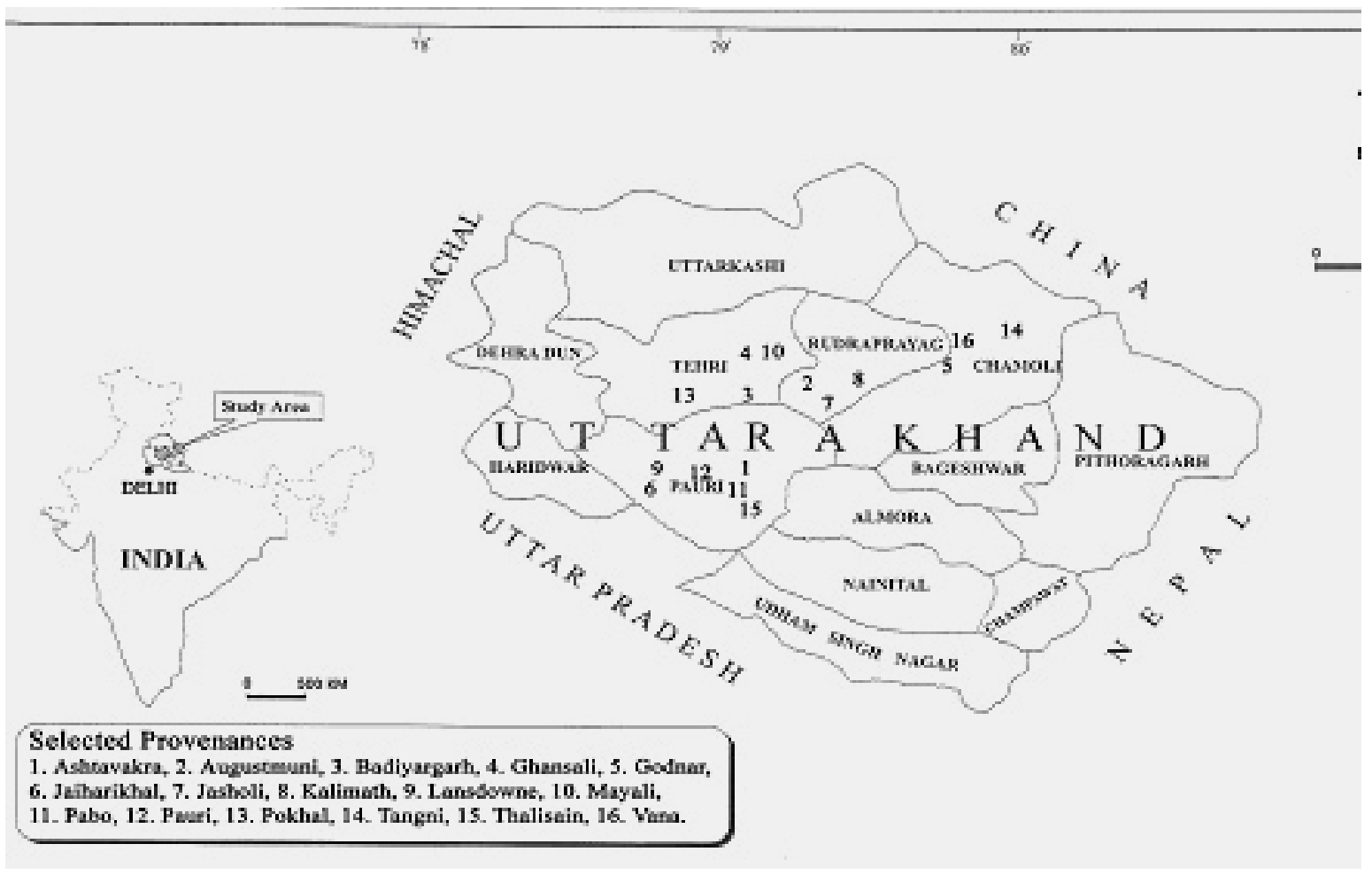

Figure 1. Location map of the study areas

The cones were collected from plus trees which were tallest, straightest, best shaped with well developed crowns and were free from pests and diseases. Ten ripe cones per tree were collected at random from the selected plus trees for recording the seeds length, width and thickness of randomly selected seeds ( 8 replicates of 20 seeds each) for each seed source. Seed weight of 800 seeds of each seed source ( 8 replicates of 100 seeds each) was recorded in order to verify the variation in seed weight. The seeds of different provenances having same level of ripeness were collected and subjected to viability test by floating method to select only the viable seeds. Seed germination in all the provenances was carried out under laboratory conditions at $25^{\circ} \mathrm{C}$ temperature, inside a seed germinator (Model No. 8LT-SGL CALTAN) after applying following presowing treatments to each set:

Treatment 1 - Soaking of the seeds in distilled water at room temperature $\left(25^{\circ} \mathrm{C}\right)$ for 24 hours.

Treatment 2- Soaking of the seeds in Hydrogen peroxide $\left(\mathrm{H}_{2} \mathrm{O}_{2} \quad 1 \% \mathrm{v} / \mathrm{v}\right)$ at room temperature $\left(25^{\circ} \mathrm{C}\right)$ for 24 hours.

Observations were recorded daily regarding germinated /non-germinated seeds up to 21 days. Radical emergence was taken as the criteria for germinability. The collected data were further quantified in terms of percent germination and germination value. Percent germination was the value of seeds germinated at the completion of the germination period, whereas, germination value is an index, combining speed and completeness of germination; which according to Czabator (1962) can be expressed as: $\mathrm{GV}=\mathrm{PV} \mathrm{X}$ MDG, where, $\mathrm{GV}$ is germination value, $\mathrm{PV}$ is the peak value of germination, and MDG is the mean daily germination. The critical difference (CD) was calculated as: $\mathrm{CD}=\mathrm{SEd} \mathrm{X} \mathrm{t}_{0.01}$, Where, SEd is the standard error of difference calculated as $\mathrm{SEd}=\sqrt{ } 2 \mathrm{Me} / \mathrm{r}$, where $\mathrm{Me}=$ mean sum of square and $\mathrm{r}=$ number of 
replicates. The variation in growth and biomass production in different provenances was recorded by transferring the laboratory germinated seedlings to polythene bags containing potting mixture of sand, soil and FYM in the ratio of 1:1:1. The polythene bags containing seedlings were placed in randomized block design, with three replications of each provenance in the homogenous net house conditions. Initially, watering was done daily up to four weeks and thereafter, at 3 days interval, till the commencement of the rainy season. The data on height and root length were recorded at the end of four months.

\section{Results and Discussion}

The results obtained on seed characteristics are presented in Table 2.

Table 2. Seed characteristics, Germination percentage and Seedling growth in different provenances of Pinus roxburghii from Garhwal Himalaya.

\begin{tabular}{|l|c|c|c|c|}
\hline Provenances & $\begin{array}{l}\text { Seeds weight } \\
\text { with wings } \\
(\mathbf{g m})\end{array}$ & $\begin{array}{l}\text { Seed } \\
\text { Length } \mathbf{( m m})\end{array}$ & $\begin{array}{l}\text { Seed } \\
\text { Width } \\
(\mathbf{m m})\end{array}$ & $\begin{array}{l}\text { Seed } \\
\text { Thickness } \\
(\mathbf{m m})\end{array}$ \\
\hline Pokhal & $13.36 \pm 0.40$ & $9.34 \pm 0.23$ & $5.28 \pm 0.17$ & $3.33 \pm 0.18$ \\
Godnar & $11.02 \pm 0.53$ & $8.25 \pm 0.20$ & $4.72 \pm 0.28$ & $2.82 \pm 0.14$ \\
Kalimath & $14.00 \pm 0.51$ & $9.42 \pm 0.33$ & $5.35 \pm 0.21$ & $3.61 \pm 0.21$ \\
Agustmuni & $11.96 \pm 0.48$ & $9.14 \pm 0.31$ & $4.80 \pm 0.25$ & $3.02 \pm 0.17$ \\
Jasholi & $13.26 \pm 0.65$ & $10.12 \pm 0.25$ & $5.65 \pm 0.27$ & $3.85 \pm 0.23$ \\
Tangni & $15.02 \pm 0.55$ & $10.80 \pm 0.27$ & $5.80 \pm 0.21$ & $4.23 \pm 0.20$ \\
Vana & $13.76 \pm 0.59$ & $10.65 \pm 0.21$ & $5.84 \pm 0.27$ & $4.12 \pm 0.18$ \\
Ashtavakra & $12.66 \pm 0.38$ & $10.08 \pm 0.27$ & $5.35 \pm 0.22$ & $3.86 \pm 0.15$ \\
Mayali & $11.89 \pm 0.47$ & $9.36 \pm 0.30$ & $5.08 \pm 0.15$ & $3.65 \pm 0.24$ \\
Jaiharikhal & $12.78 \pm 0.60$ & $9.40 \pm 0.35$ & $5.56 \pm 0.23$ & $3.23 \pm 0.20$ \\
Lansdowne & $13.98 \pm 0.54$ & $10.28 \pm 0.29$ & $6.35 \pm 0.28$ & $4.07 \pm 0.17$ \\
Pauri & $14.27 \pm 0.42$ & $9.99 \pm 0.20$ & $5.51 \pm 0.21$ & $3.49 \pm 0.19$ \\
Ghansali & $14.88 \pm 0.49$ & $10.56 \pm 0.29$ & $5.89 \pm 0.26$ & $4.01 \pm 0.14$ \\
Thalisain & $15.67 \pm 0.37$ & $10.98 \pm 0.24$ & $6.98 \pm 0.18$ & $4.40 \pm 0.21$ \\
Pabo & $15.48 \pm 0.64$ & $10.30 \pm 0.27$ & $5.84 \pm 0.15$ & $3.94 \pm 0.16$ \\
Badiyargarh & $12.78 \pm 0.58$ & $8.48 \pm 0.32$ & $5.36 \pm 0.23$ & $3.44 \pm 0.25$ \\
\hline F-test & $3.890 *$ & 0.0614 & 0.266 & $2.132 *$ \\
\hline P-value & 0.0006 & 1.00 & 0.9956 & 0.0355 \\
\hline LSD & 1.8174 & 0.8576 & 0.6126 & 0.5922 \\
\hline SD & 0.803 & 0.559 & 0.447 & 1.339 \\
\hline CV\% & 8.176 & 10.006 & 12.117 & 9.881 \\
\hline
\end{tabular}

*significant at 5\% level.

**ArcSine values are given in parenthesis 
Table 2. cont.

\begin{tabular}{|l|c|c|c|c|}
\hline Provenances & $\begin{array}{c}\text { Germination } \\
\text { percentage } \\
\text { (control)** }\end{array}$ & $\begin{array}{c}\text { Germination value } \\
\text { (control) }\end{array}$ & $\begin{array}{c}\text { Germination } \\
\text { percentage } \\
\left(\mathbf{H}_{\mathbf{2}} \mathbf{O}_{\mathbf{2}} \mathbf{1 \%} \mathbf{v} / \mathbf{v}\right)^{* *}\end{array}$ & $\begin{array}{c}\text { Germination } \\
\text { value } \\
\left(\mathbf{H}_{2} \mathbf{O}_{\mathbf{2}} \mathbf{1 \%} \mathbf{v} / \mathbf{v}\right)\end{array}$ \\
\hline Pokhal & $82.2 \pm 2.06(65.05)$ & $10.88 \pm 1.18$ & $88.4 \pm 0.75(70.09)$ & $18.29 \pm 1.61$ \\
Godnar & $84.0 \pm 7.42(66.42)$ & $7.88 \pm 2.08$ & $80.4 \pm 1.17(63.72)$ & $13.24 \pm 1.21$ \\
Kalimath & $97.6 \pm 1.17(81.09)$ & $6.05 \pm 1.54$ & $98.4 \pm 0.75(82.73)$ & $7.64 \pm 0.80$ \\
Agustmuni & $75.2 \pm 1.02(60.13)$ & $18.39 \pm 2.57$ & $83.2 \pm 1.02(65.80)$ & $14.97 \pm 0.94$ \\
Jasholi & $73.2 \pm 1.86(58.82)$ & $6.35 \pm 0.79$ & $80.0 \pm 1.42(63.44)$ & $6.10 \pm 0.81$ \\
Tangni & $38.0 \pm 1.67(38.06)$ & $3.25 \pm 1.31$ & $84.0 \pm 1.48(66.42)$ & $17.68 \pm 1.03$ \\
Vana & $89.6 \pm 1.72(71.19)$ & $16.1 \pm 1.59$ & $95.2 \pm 1.02(77.34)$ & $36.94 \pm 5.10$ \\
Ashtavakra & $92.4 \pm 1.47(74.00)$ & $28.9 \pm 0.99$ & $94.0 \pm 1.10(75.82)$ & $69.97 \pm 5.74$ \\
Mayali & $81.6 \pm 1.17(64.60)$ & $24.43 \pm 1.99$ & $88.0 \pm 0.90(69.73)$ & $66.62 \pm 2.87$ \\
Jaiharikhal & $71.2 \pm 1.02(57.54)$ & $4.14 \pm 1.37$ & $85.2 \pm 1.02(67.37)$ & $19.48 \pm 1.74$ \\
Lansdowne & $79.6 \pm 1.60(63.15)$ & $3.61 \pm 0.73$ & $92.4 \pm 0.75(74.00)$ & $25.64 \pm 1.59$ \\
Pauri & $85.6 \pm 1.17(67.70)$ & $4.81 \pm 1.65$ & $90.4 \pm 1.17(71.95)$ & $32.19 \pm 2.35$ \\
Ghansali & $74.8 \pm 2.06(59.87)$ & $3.94 \pm 0.89$ & $91.2 \pm 1.10(72.74)$ & $37.33 \pm 1.96$ \\
Thalisain & $90.0 \pm 1.42(71.56)$ & $7.26 \pm 0.86$ & $96.0 \pm 0.90(78.46)$ & $43.57 \pm 1.95$ \\
Pabo & $84.0 \pm 2.42(66.42)$ & $5.49 \pm 0.94$ & $85.2 \pm 1.02(67.37)$ & $24.38 \pm 1.69$ \\
Badiyargarh & $39.2 \pm 1.36(38.76)$ & $2.84 \pm 0.74$ & $83.6 \pm 1.33(66.11)$ & $17.85 \pm 2.33$ \\
\hline F-test & & & & \\
\hline P-value & $48.6175 *$ & $45.049 *$ & $9.341 *$ & $212.436 *$ \\
\hline LSD & $1 \mathrm{E}-17$ & $3.15 \mathrm{E}-17$ & $8.02 \mathrm{E}-08$ & $1.17 \mathrm{E}-27$ \\
\hline SD & 20.6650 & 10.2917 & 6.9224 & 23.4626 \\
\hline CV\% & 16.773 & 8.036 & 5.702 & 18.896 \\
\hline
\end{tabular}

*significant at $5 \%$ level.

**ArcSine values are given in parenthesis

Weight of 100 seeds in various provenances/seed sources ranged from $11.02 \pm 0.53 \mathrm{~g}$ (Godnar) to $15.67 \pm 0.37 \mathrm{~g}$ (Thalisain). The mean weight of 100 seeds in Pabo (15.48 $\pm 0.64 \mathrm{~g})$, Tangni $(15.02 \pm 0.55 \mathrm{~g})$, Ghansali $(14.88 \pm 0.49 \mathrm{~g})$ and Pauri $(14.27 \pm 0.42 \mathrm{~g})$ seed sources were close to the maximum seed weight. The maximum seed length was observed $(10.98 \pm 0.24 \mathrm{~mm})$ for Thalisain seed source and minimum $(8.25 \pm 0.20 \mathrm{~mm})$ for Godnar seed source. The existing variation for seed width was low as compared to seed length and thickness. The seed width varied between $4.72 \mathrm{~mm}$ (Godnar) to $6.98 \mathrm{~mm}$ (Thalisain), similarly, the maximum seed thickness $(4.40 \pm 0.21 \mathrm{~mm})$ was revealed by Thalisain seed source, however, the thinnest seeds were produced by Godnar seed source $(2.82 \pm 0.14 \mathrm{~mm})$.

Germination of seeds in various seed sources after pre-soaking treatment $\left(\mathrm{H}_{2} \mathrm{O}_{2}\right.$ $1 \% \mathrm{v} / \mathrm{v})$ under $25^{\circ} \mathrm{C}$ temperature has yielded significant differences in seed germination. The maximum germination percentage $(98.4 \pm 0.75 \%)$ was recorded for Kalimath seed source, and minimum $(80.0 \pm 1.42 \%)$ for Jasholi seed source. However, the higher germination value $(69.97 \pm 5.74)$ was recorded for Ashtavakra, and lower $(6.10 \pm 0.81)$ for Jasholi seed source. Under control conditions the highest germination percentage $(97.6 \pm 1.17 \%)$ was recorded for Kalimath seed source and lowest $(38.0 \pm 1.67 \%)$ for Tangni seed source. Similarly, the highest germination value $(28.09 \pm 0.99)$ was recorded for Ashtavakra, whereas, lowest germination value for Badiyargarh seed source $(2.84 \pm 0.74)$.

The performance of seedlings raised from Pabo seed source was superior, having maximum height $(10.16 \pm 0.37 \mathrm{~cm})$, and minimum seedling height $(8.70 \pm 0.29 \mathrm{~cm})$ was recorded for Agustmuni seed source. The highest root length was recorded for the 
seedlings of Pabo seed source $(14.62 \pm 0.53 \mathrm{~cm})$, and lowest $(12.38 \pm 0.63 \mathrm{~cm})$ for Mayali seed source (Table 2.).

Simple correlation was calculated between seed characteristics, germination characteristics and geographic parameters viz., altitude, mean annual rainfall ( $\mathrm{mm})$, longitude and latitude, etc., results of which are presented in Table 3.

Table 3. Simple correlation coefficients between seed characteristics and geographic variation.

\begin{tabular}{lcccccc}
\hline Characters & \multicolumn{1}{c}{$\mathbf{1}$} & \multicolumn{1}{c}{$\mathbf{2}$} & $\mathbf{3}$ & $\mathbf{4}$ & $\mathbf{5}$ & $\mathbf{6}$ \\
\hline Seed length (mm) & 1.000 & & & & & \\
Seed width (mm) & $0.797^{*}$ & 1.000 & & & & \\
Seed thickness (mm) & $0.904^{*}$ & $0.840^{*}$ & 1.000 & & & \\
100-Seed weight (gm) & $0.811^{*}$ & $0.812^{*}$ & $0.783^{*}$ & 1.000 & & \\
Germination \% (control) & 0.124 & 0.048 & -0.005 & -0.007 & 1.000 & \\
Germination value & -0.074 & -0.379 & -0.086 & -0.479 & $0.394^{* *}$ & 1.000 \\
Germination \% ( $\left.\mathrm{H}_{2} \mathrm{O}_{2} 1 \% \mathrm{v} / \mathrm{v}\right)$ & $0.464^{* *}$ & $0.470^{* *}$ & $0.499^{* *}$ & $0.429^{* *}$ & $0.579^{* *}$ & 0.189 \\
Germination value & $0.302^{* *}$ & 0.152 & $0.354^{* *}$ & -0.007 & $0.314^{* *}$ & $0.695^{*}$ \\
Seedling height (cm) & 0.290 & 0.228 & $0.410^{* *}$ & $0.476^{* *}$ & -0.169 & -0.280 \\
Root length (cm) & -0.066 & -0.015 & 0.016 & 0.264 & -0.062 & -0.487 \\
Altitude (m) & 0.198 & $0.331^{* *}$ & $0.338^{* *}$ & 0.108 & 0.103 & 0.119 \\
Mean annual rainfall (mm) & -0.074 & -0.135 & -0.035 & -0.122 & -0.309 & 0.014 \\
Latitude N & -0.182 & 0.031 & -0.196 & -0.219 & 0.215 & 0.046 \\
Longitude E & 0.247 & $0.550^{* *}$ & $0.377^{* *}$ & 0.247 & 0.290 & -0.113 \\
\hline
\end{tabular}

Significant at $1 \%$ level $\& * *$ significant at $5 \%$ level

\begin{tabular}{lcccccc}
\hline Characters & $\mathbf{7}$ & $\mathbf{8}$ & $\mathbf{9}$ & $\mathbf{1 0}$ & $\mathbf{1 1}$ & $\mathbf{1 2}$ \\
\hline Seed length (mm) & & & & & & \\
Seed width (mm) & & & & & & \\
Seed thickness (mm) & & & & & & \\
100-Seed weight (gm) & & & & & & \\
Germination \% (control) & & & & & & \\
Germination value & & & & & & \\
Germination \% ( $\left.\mathrm{H}_{2} \mathrm{O}_{2} 1 \% \mathrm{v} / \mathrm{v}\right)$ & 1.000 & & & & & \\
Germination value & $0.447^{* *}$ & 1.000 & & & & \\
Seedling height (cm) & -0.121 & -0.174 & 1.000 & & & \\
Root length (cm) & -0.129 & -0.494 & $0.789^{*}$ & 1.000 & & \\
Altitude (m) & 0.119 & $0.371^{* *}$ & 0.185 & 0.016 & 1.000 & \\
Mean annual rainfall (mm) & -0.340 & -0.023 & 0.079 & -0.020 & 0.556 & 1.000 \\
Latitude N & 0.076 & -0.091 & -0.289 & -0.286 & -0.047 & 0.093 \\
Longitude E & 0.199 & 0.103 & 0.202 & 0.049 & $0.396^{* * *}$ & 0.090 \\
\hline
\end{tabular}

Significant at $1 \%$ level \& ** significant at $5 \%$ level

Statistically negative correlation was observed between germination value and seed characteristics. A significant positive correlation was observed between seed germination $\left(\mathrm{H}_{2} \mathrm{O}_{2} 1 \% \mathrm{v} / \mathrm{v}\right)$ and other seed parameters. Latitude and longitude were found to be significantly and positively correlated with germination of chirpine seeds under normal (control) conditions (0.215 and 0.290) and when treated with $\mathrm{H}_{2} \mathrm{O}_{2}(0.076$ and 0.199). Germination value of the $\mathrm{H}_{2} \mathrm{O}_{2}$ treated seeds showed negative correlation 
with latitude, and positive correlation with longitude, whereas, seeds under controlled conditions showed positive correlation with latitude and negative correlation with longitude. Correlation between germination percentage and rainfall was negative in all the seeds treated and germination under controlled conditions, whereas significantly positive correlation was observed between rainfall and altitude $(r=0.556)$. Except for seedling height and germination value of seeds grown under controlled conditions all the other parameters of seed characteristics and germination characteristics were found to be negatively correlated with rainfall. $\mathrm{H}_{2} \mathrm{O}_{2}$ treatment showed significant effect on seed germination percent in all the seed sources except Godnar seed source (Table 2).

It is apparent from the results that seed sources, which had higher values for seed parameters, also showed better performance in germination. These findings have been supported by the concept of Baldwin (1942) and Dunlap and Barnett (1983), according to which, seed size and weight have pronounced effects on seed germination. Generally, large seeds have fast and uniform germination, due to more endosperm nutrient pool (Kandya, 1978). Therefore, seed source variation in germination percent and related traits may be ascribed to the differences in seed dimensions and weight. Germination values varied considerably among seed sources and exhibited a random pattern. Germination value is an index of combining speed and completeness of germination, which itself is a function of seed size and weight (Czabator, 1962; Dunlap \& Barnett, 1983). On the other hand, variation observed in time taken to complete germination could be attributed to the differences in germination rate and germination value of the selected provenances. Significant variation in germination values among seed sources is in conformity with those found in fir and spruce by Singh and Singh (Singh \& Virendra Singh, 1981).

Soaking the seeds for 24 hours in a solution of $\mathrm{H}_{2} \mathrm{O}_{2}(1 \% \mathrm{v} / \mathrm{v})$ had a significant effect on the rate of germination and average germination percentage. About $88.5 \%$ of mean average germination was revealed by the seeds that were treated with $\mathrm{H}_{2} \mathrm{O}_{2}$, while the mean average germination percentage of untreated (control) seeds was just $77.4 \%$ (Table 2). Simultaneously, $\mathrm{H}_{2} \mathrm{O}_{2}$ treatment also caused an appreciable decrease, in shortening of germination period by 10 days. Similar results were recorded by Chandra and Chauhan (1976) in Picea smithiana and Shafiq (1980) in Nothofagus obliqua and Nothofagus procera seeds. Thus, soaking of chir-pine seeds in $\mathrm{H}_{2} \mathrm{O}_{2}(1 \% \mathrm{v} / \mathrm{v})$ for 24 hours is highly beneficial and therefore for large scale germination, treatment of $\mathrm{H}_{2} \mathrm{O}_{2}$ should be preferred, since it also involves the saving of expenditure as compared to other hormones. The cost involved in case of $\mathrm{H}_{2} \mathrm{O}_{2}$ will be approximately half of the cost of other hormones. It was also evident from the results that although the $\mathrm{H}_{2} \mathrm{O}_{2}$ improved the germination of seeds in all the sources, still there were variations in its effect on rate of the germination in the provenances, which may be due to variation in geographical locations and the altitude of the seed sources (Holm, 1994; Barnett, 1997; Vera, 1997). Differences in the rate of germination in the provenances have also been documented by Webb and Farmer (1968), Wilcox (1968) and Tewari et al. (2001). It is clear from the results that the sexual reproductive efficiency, which can be assessed by determining germination capacity may vary with altitude. Thus, altitudinal provenances of a species may differ not only in seed germination but also in their reproductive efficiency.

The seed sources varied significantly among themselves with respect to field survival and growth parameters (Table 2.) during all stages of measurements. The seedlings of different provenances, when grown under common nursery environmental conditions, 
often displayed different patterns of shoot growth (Dormling, 1979; Rehfeldt \& Wycoff, 1981). However, it is not always easy to show that such differences are adaptive, presumably in response to the environment of the parent seed origin. Analysis of variation in growth-related traits of several tree species indicated that some portion of the total variation might be under strong genetic control, which is of adaptive importance and leads to the differentiation into distinct populations. In the present investigation, since seeds of all seed sources were raised under common nursery conditions, the environmental influences being reduced to minimal, therefore, variation among seed sources in field emergence and growth may be interpreted as genetic. Sniezko and Stewart (1989) were of the view that the provenance, and within provenance variation in nursery traits is essentially genetic in nature.

\section{REFERENCES}

[1] Baldwin, H.I. (1942): Forest tree seeds of the north temperate region with special reference to North America. - Chronica Botanica Co. Waltham, Mass. pp. 240.

[2] Barnett, J.P. (1997): Relating pine seed coat characteristics to speed of germination, geographic variation, and seedling development. - Tree Planters Notes 48(1-2): 38-42.

[3] Chandra, J.P., Chauhan, P.S. (1976): Note on germination of spruce seeds with gibberellic acid. - Indian Forester 102(10): 721-725.

[4] Czabator, F.J. (1962): Germination Value: an index combining speed and completeness of Pine seed germination. - Forest Science 8: 386-396.

[5] Dormling, I. (1979): Influence of light intensity and temperature on photoperiodic response of Norway spruce provenances. - In: Proc. IUFRO Norway spruce Meeting, Bucharest, pp. 398-408.

[6] Dunlap, J.R., Barnett, J.P. (1983): Influence of seed size on germination and early development of loblolly pine (Pinus taeda L.) germinants. - Canadian Journal of Forest Research 13: 40-44.

[7] Ghildiyal, S.K. (2003): Provenance testing in Pinus roxburghii from Western-central Himalaya. Ph.D. thesis. - H.N.B. Garhwal University Srinagar Garhwal Uttaranchal, India.

[8] Ghildiyal, S.K., Sharma, C.M. (2005): Effect of seed size and temperature treatments on germination of various seed sources of Pinus wallichiana and Pinus roxburghii from Garhwal Himalaya. - Indian Forester 131(1): 56-65.

[9] Ghildiyal, S.K., Sharma, C.M. (2007): Genetic parameters of cone and seed characters in Pinus roxburghii. - Proceedings of the National Academy of Sciences, India 77(B), II: 186-191.

[10] Ghildiyal, S.K., Sharma, C.M., Khanduri, V.P. (2007): Improvement of germination in Chirpine by treatment with Hydrogen peroxide. - Journal of Tropical Forest Science 19(2): 113-118.

[11] Holm, S.O. (1994): Reproductive patterns of Betula pendula and B. pubscens collected along a regional altitudinal gradient in Sweden. - Ecography 17: 60-72.

[12] Hussain, A. (1995): Untersuchungen zur genetischen kontrolle von Isoenzym- Polymorphismen und zur genetischen struktur von Pinus roxburghii Sarg. Dissertation des doktorgrades des Forstwissenschaftlichen Fachbereichs der Georg - August Universitat Goettingen.

[13] Kandya, A.K. (1978): Relationship among seed weight and various growth factors in Pinus oocarpa seedlings. - Indian Forester 104(8): 561-567.

[14] Kitzmiller, J.H. (2005): Provenance trials of Ponderosa Pine in Northern California. - Forest Science 51(6): 595-607.

[15] Knipe, D.D. (1973): Western wheat grass germination as related to temperature, light and moisture stress. - Journal of Range Management 26: 68-69.

[16] Ledig, F.T., Kitzmiller, J.H. (1992): Genetic strategies for reforestation in the face of global climate change. - Forest Ecology and Management 50: 153-169. 
[17] Quarberg, D., Jahns, T.R. (2000): Wet-towel germination test. - UAF-Cooperative Extension Service Publication \# FGV-00249, pp. 1-4.

[18] Rao, P.B., Singh, S.P. (1985): Response breadth on environmental gradients of germination and seedling growth in two dominant forest tree species of Central Himalaya. - Annals of Botany 56: 783-794.

[19] Rehfeldt, G.E., Wycoff, W.R. (1981): Periodicity in shoot elongation among populations of Pinus contorta from northern Rocky Mountains. - Annals of Botany 48: 371-377.

[20] Shafiq, Y. (1980): Effect of gibberellic acid $\left(\mathrm{GA}_{3}\right)$ and pre-chilling on germination per cent of Nothofagus obliqua (Mirb.)Oerst. and N. procera Oerst. seeds. - Indian Forester 106(1): 27-33.

[21] Sharma, C.M., Ghildiyal, S.K., Nautiyal, D.P. (2001): Plus tree selection and their seed germination in Pinus roxburghii from Garhwal Himalaya. - Indian Journal of Forestry 24: 4852.

[22] Sharma, K. (1999): Genetic variability and population structure of Pinus roxburghii Sarg. - In India Ph. D. thesis, FRI Deemed University Dehra Dun.

[23] Sharma, R. (2007): Variation studies in provenances and plus trees of Pinus roxburghii Sarg. Indian Forester 133(2): 519-526.

[24] Singh, R.V., Virendra Singh (1981): Preliminary studies on the quality of spruce and silver fir seeds as affected by its source. - Indian Forester 107(9): 571-577.

[25] Sniezko, R.A., Stewart, H.T.L. (1989): Range-wide provenance variation in growth and nutrition of Acacia albida seedlings propagated in Zimbabwe. - Forest Ecology and Management 27 (3-4): 179-197.

[26] Tewari, P., Tewari, A., Jeet Ram (2001): Seed characteristics and germination behaviour of some important coniferous trees of central Himalaya, India. - Journal of Tropical Forest Science 13(1): $140-147$.

[27] Thapliyal, R.C., Uniyal, D.P., Rawat, M.S. (1985): Variation in germination characteristics of some seed origins of Pinus wallichiana A B Jacks from the Western Himalaya. - Proceedings of Indian Academy of Science (Plant Science) 95(6): 441-451.

[28] Vera, M.L. (1997): Effects of altitude and seed size on germination and seedling survival of heathland plants in north Spain. - Plant Ecology 133: 101-106.

[29] Webb, D.C., Farmer, R.E. (1968): Sycamore seed germination: The effects of provenance, stratification, temperature and parent tree. - USDA Forest Service Research Note SE-100, pp. 6.

[30] Wilcox, J.R. (1968): Sweetgum seed stratification requirements related to winter climate at seed source. - Forest Science 14: 16-19. 